\title{
Political Representation of Ethnic Minorities at Local Level: Factors, Context and Empirical Examples
}

\section{Martin Kryšpín Vimmr ${ }^{1}$}

\begin{abstract}
This qualitative comparative study examines all sorts of the factors which have influence on the political representation of ethnic minorities at a local level. Two dependent variables are analyzed on the four empirical cases: the level of proportionality of political representation and nature of political representation of ethnic minorities. Influence of three different independent variables is discussed further on. These variables are an electoral system, special measures for minority representation and electoral rights as all these variables could possibly have an effect on the level of political representation of ethnic minorities. The selected cases are the cities of Leicester, United Kingdom, the Finnish city of Espoo, ClujNapoca in Romania and Frankfurt am Main in Germany. All these cases have a substantial amount of citizens of different ethnic groups.

This paper was supported by Grant Agency of Charles University, project number 274415 named „Program, ideologie a činnost etnoregionálních stran na komunální úrovni“.
\end{abstract}

Keywords: minority representation; ethnic politics; local politics; ethnic minorities; minority inclusion

\section{Introduction}

The questions of an ethnic conflict and ethnic representation have been receiving a lot of attention over time within the field of political science. Most of the major texts concerning this topic examine ethnic issues only on the national level of a political system. This is quite understandable as many of the demands proposed by ethnic minorities are aimed towards the central government. However, everyday life of ethnic minority groups is directly influenced by lower levels of a political system (e.g. regional and local) as well. Inclusion of a local perspective into the topic of ethnic representation is one of the main aims of this paper as there exists no coherent text ${ }^{2}$ regarding this topic. Various events from different

1 Martin Kryšpín Vimmr (1989), U Kříže 661/8, 158 00, Praha 5 - Jinonice, Czech Republic, Institute of Political Science, Faculty of Social Sciences, Charles University in Prague, martin.kryspin.vimmr@fss.cuni.cz

2 At least there exists no such text in either English, German or Czech language. 
countries are described in the next section to put the problematic in the wider context.

In October 2013, tens of thousands of ethnic Hungarians marched to draw attention to the situation of Hungarians in Romania and to call for a wider autonomy for this ethnic group. It was a repeated demonstration of ethnic tension between the majority population in Romania and the Hungarian minority (Týden.cz 2013). Four months earlier, in June 2013, a similar manifestation took place at the other end of Europe in the English city of Leicester. But in this case the situation was the opposite. The manifestation march was organized by the movement called the English Defence League (EDL), which represents a more radical part of the British majority. The aim of this manifestation was to point out the supposed dangers which are according to this organization represented by immigrants from other (primarily all Muslim) countries (Leicester Mercury 2013). In March of the same year, ethnic clashes between young Macedonians and Albanians took place in Skopje, Macedonia. Twenty-two people were injured during the riots triggered by Macedonian protests against the appointment of the Minister of Defence who is of Albanian origin. This minister was unacceptable for a Macedonian part of population as he was a leader of the Albanian opposition during the similar clashes in 2001 (IDNES.CZ 2013).

All the cases described above illustrate a very well-known phenomenonthat all sorts of ethnic protests and clashes physically take place at a local level (even though their meaning could have nationwide scope). In other similar cases the local events became a trigger for widespread ethnic tension. A local level is also the space where different ethnic groups physically meet (which is particularly true in case of larger cities). A local perspective thus opens a whole new approach on how to study an ethnic conflict. This approach could answer the questions regarding the nature and political behaviour of ethnic minorities as well as examine what are the specifics of this level in comparison to the self-governments at the other levels in case of the questions related to ethnic minorities. The trend of ongoing decentralization and strengthening of local self-governments, which may be recently observed in most European countries, could thus help the regulation of an ethnic conflict in the very places which could be its source.

\section{Current state of knowledge and theoretical backgound}

As it has already been mentioned, there is no coherent text regarding the ethnic conflict and ethnic participation at a local level. However, there are a lot of authors from different fields who examine ethnic conflict in general. Ernest 
Gellner (1993) in sociology, Thomas Hylland Eriksen (2012) in anthropology, Anthony D. Smith $(1986,1996)$ or Filip Tesař $(2007)$ in ethnology and finally Benedict Anderson (1991), Donald Horowitz (1985), Pavel Barša and Maxmilián Strmiska (1999) in political science. In political science, especially is where the term conflict is understood in a broader sense. It is perceived not only as a violent conflict, but also as a political, institutionalized type of conflict (Barša, 1999, p. 47). The main interest of political science in this type of research lies in the question of the regulation of an ethnic conflict. One of the important approaches which help to understand this problem is the theory of cleavages introduced by Stein Rokkan and Seymour M. Lipset in 1967 in their book Systems and Voter Alignments: Cross-national Perspective (Lipset, Rokkan, 1967). Their theory offers a systematic view on all sorts of political conflicts within modern democracies; therefore, it also discusses ethnic conflicts. Another theory which attempts to find a solution to ethnically divided societies is the theory of consociational democracy. This theory was created by Arend Lijphart throughout the 1970s (Lijphart, 1968, 1980). In his work, Lijphart uses an example of "pillar society" that could be found in the $60 \mathrm{~s}$ and $70 \mathrm{~s}$ in the Netherlands. The theory of consociational democracy gives a certain prescription on how to include a political representation of all the minority groups into the political process and how to avoid the escalation of potential conflicts. Another important author who similarly examines democracy in ethnically divided societies is Donald Horowitz (1985). Federalism should also be mentioned as a solution known from practice. Federation as a strongly decentralized model allows regionally concentrated minorities to easily enforce their interests. However, on the other hand, by giving more autonomy to individual states, federation could also strengthen separatist tendencies and could lead to dissolution in the end. Probably the most cited example, where federation was implemented to regulate an ethnic conflict is Nigeria (Adegehe, 2009, p. 24).

The aforementioned three different approaches illustrate very well how most of the concepts focus on the central level of a political system. That is quite understandable as most of the important legislature regarding ethnic minorities is created on this level. However, such an approach overlooks the fact that members of minority groups most often communicate with state at a local level. The decisions made at a local level have impact on the quality of their life in the areas of healthcare or education. Culture, which is very important for ethnic minorities, is also often decided at a local level. All sorts of integration policies are implemented by local self-governments as well. These policies often include the incentives for minority employment or development of neighbourhoods 
inhabited mostly by ethnic minorities ${ }^{3}$. One way or another, local politics can have an important impact on the life of ethnic minorities; therefore, it should not be overlooked by researchers.

\section{Methodology and case selection}

This paper aims to examine the phenomenon of a political representation of ethnic minorities at a local level with a special focus on the factors that influence this representation. Empirical cases and their different models of representation with identification of all sorts of factors should serve this aim. As a result, this main research question is posed:

Which factors could influence a political representation of ethnic minorities at a local level?

From the methodological point of view, this research is a comparative case study. This type of study examines a few cases and applies a comparative analysis on them. Gillham (2010, p. 11) writes that this method is ideal for the topics which have not yet been analysed and it may prepare the background for a future quantitative analysis of more cases. This type of research examines the topic in context and unlike single-case studies, it may allow some level of generalisation.

The proportionality of representation and nature of ethnic representation were chosen as dependent variables. The proportionality of representation $(R)$ says to what extent an ethnic minority is over or underrepresented. It is expressed by proportionality index which is calculated by dividing percentage share of ethnic councillors within the municipal council (c) by percentage share of minority population in the examined municipality $(p)$. The simple formula to calculate a proportionality index is, therefore, as follows:

$$
R=\frac{c}{p}
$$

Where $\mathrm{R}=1$ means a perfect proportionality. The result over 1 means overrepresentation and result below 1 means underrepresentation. The second dependent variable, nature of ethnic representation, relates to the type of a political subject ethnic minorities use for their representation.

3 As it is very difficult to clearly define ethnic minority, for research purposes, the definitions from official statistics were used for each case. There are only minor differences in definition of every examined country; however, the definitions used by statistical offices are described later in the text. 
Table 1: Dependent variables

\begin{tabular}{|l|l|}
\hline Dependent variable & Operationalization \\
\hline $\begin{array}{l}\text { Proportionality of ethnic representa- } \\
\text { tion }\end{array}$ & $R=\frac{c}{p}$ \\
\hline Nature of ethnic representation & $\begin{array}{l}\text { 1) represented by non-ethnic nati- } \\
\text { onwide parties } \\
\text { 2) represented by ethnic or regional } \\
\text { parties } \\
\text { 3) another form of representation (for } \\
\text { example, independent candidates) }\end{array}$ \\
\hline
\end{tabular}

Source: author

The factors that could influence the nature and proportionality of an ethnic representation were chosen as independent variables. As Irene Bloemraad and Karen Schönwalder remark, an electoral system and its specifications are one of the major factors which determine a political representation of ethnic minorities (Bloemraad, Schönwalder, 2013, p. 571). An electoral system and voting rights (both passive and active) were, therefore, decided to be the first two independent variables. Operationalization of the electoral system was based on voting mechanics (plurality vote or proportional list) and the level of vote personalization as this could have major impact on the minority representation. A voting right was divided according to a criterion of how broad it is and whether it includes foreigners and minority citizens. In most of the EU countries, a voting right is limited to all the EU citizens who have residency in the country for a certain period of time (which differs in each country).

Another examined independent variable is special measures that should help a political representation of ethnic minorities. The selection of this variable was based on the first monitoring of relevant cases, which showed that most European countries use some kind of such measures at a local level. However, operationalization of this variable could be problematic as each of these measures differs a lot from one to another. The contribution of this variable is thus more in its specific analysis in every single case. These measures were divided into two basic types. The first type consists of the measures with indirect effect on the minority representation. The other type contains the measures with direct impact on the minority representation. The last examined independent variable is nature of an ethnic minority. As Bloemraad and Schönwalder remark, the origins of a minority group are crucial for the nature of its political participation (Bloemraad, Schönwalder, 2013, p. 568). More specifically they point out the 
differences between autochthon minorities and immigrant groups (Bloemraad, Schönwalder, 2013, p. 568). As operationalization, minority groups are divided into three types: historic (autochthon), immigrant minorities and mixed cases.

Table 2: Operationalization of independent variables

\begin{tabular}{|l|l|}
\hline Independent variable & Operationalization \\
\hline Electoral system & $\begin{array}{l}\text { 1) plurality vote } \\
\text { 2) proportional with personalization } \\
\text { of vote } \\
\text { 3) proportional without personalizati- } \\
\text { on of vote }\end{array}$ \\
\hline $\begin{array}{l}\text { Special measures regarding the repre- } \\
\text { sentation of ethnic minorities }\end{array}$ & $\begin{array}{l}\text { 1) Measures with direct impact on } \\
\text { minority representation (quo-tas) } \\
\text { 2) formal and informal measures with } \\
\text { indirect impact on minori-ty repre- } \\
\text { sentation } \\
\text { 3) no measures }\end{array}$ \\
\hline Voting right & $\begin{array}{l}\text { 1) Broad, including foreigners under } \\
\text { certain circumstances } \\
\text { 2) Voting right extended to some } \\
\text { specifically defined groups (besides } \\
\text { the EU citizens) } \\
\text { 3) voting right for the EU citizens } \\
\text { with residency }\end{array}$ \\
\hline Nature of ethnic minority & $\begin{array}{l}\text { 1) historic minority } \\
\text { 2) immigrant minority } \\
\text { 3) mixed case }\end{array}$ \\
\hline
\end{tabular}

Source: author

It is important to point out that not all of the relations between dependent and independent variables are relevant for this research. Table 3) shows which relations are examined. 
Table 3: Examined relations between dependent and independent variables

\begin{tabular}{|l|l|}
\hline Dependent variable & Relevant independent variables \\
\hline $\begin{array}{l}\text { Proportionality of ethnic representa- } \\
\text { tion }\end{array}$ & $\begin{array}{l}\text { Electoral system } \\
\text { Voting right } \\
\text { Special measures for minority repre- } \\
\text { sentation }\end{array}$ \\
\hline Nature of ethnic representation & $\begin{array}{l}\text { Electoral system } \\
\text { Nature of ethnic minority }\end{array}$ \\
\hline
\end{tabular}

Source: author

The analysis of primary sources served as a main methodological tool used in the examination of selected cases. Original texts or documents are understood as primary sources (Pierce, 2008, p. 81). According to Hendl (2006, p. 204) these could serve as only a data base of a case study and a proper qualitative research can be built upon them. In the case of this research, primary sources are laws on municipalities and in some cases language laws. Other primary sources are the web pages of selected municipalities. These include basic information about city councillors and sometimes even their CVs and other usable information. Reports and documents created by the city council or some other state institution conclude the list of relevant primary sources.

John Stuart Mill's method of agreement, which selects cases with the same main variable and the most different other variables, was used for the case selection (Van Evera, 1997, p. 57). In our case the main variable is the existence of a political representation of ethnic minorities. This practically means that only the cases where ethnic councillors could be found are the ones that are relevant, i.e. the index of proportionality of a political representation of ethnic minorities, which has been described earlier, has to be over 0 in all the selected cases. For the basic comparability of the cases, it was also said that all the cases have to be European cities with more than 100000 inhabitants and at least $10 \%$ of minority population. Some European cities with minority population were selected in the first phase and later consulted with some other foreign experts on local politics. From all the cities that could have been potentially selected, the selection was narrowed to the following four cases as these have the best diversity in all the independent variables: Leicester (United Kingdom), Frankfurt am Main (Germany), Espoo (Finland), Cluj-Napoca (Romania). 
All these cases fulfill the first two criteria (existence of minority population and number of inhabitants) and they are very diverse in most of the other variables. They have different local political systems and different restrictive voting rights. Their local political systems are different according to the vertical typologies of local governments and their ethnic minorities have different origins (immigrant, historical or mixed) (Heinelt, Hlepas, 2006, p. 26). The only criterion which is not different for all the cases is the parameters of their local governments according to the so-called horizontal dimension. In this matter we can only find a model of a strong mayor form and collective form (Heinelt, Hlepas, 2006, p. 31, Swianiewicz, 2014, p. 304). This is, however, the natural empirical limitation, because in practice it is almost impossible to find cases which would be different in all the aspects.

\section{Results of case analysis}

The following part introduces and discusses the results of case analysis of all four above mentioned cases. First of all the first independent variable - proportionality of ethnic representation - is examined. Then the possible influence of all independent variables is discussed for each of them separately. And finally the second dependent variable - nature of ethnic representation - is examined at the end of this part.

\section{Proportionality of ethnic representation}

The first examined dependent variable is a proportionality of ethnic representation. This variable shows to what extent ethnic minority groups in the selected case are over or underrepresented. It is expressed by index of proportionality as it has already been described earlier. Table 4) gives an overview of percentage shares of ethnic minorities in population of the selected municipalities as well as shares in their city councils and executive bodies. It also gives final values of proportionality index. These values are all surprisingly similar with an exception of Frankfurt am Main. The case of Frankfurt is quite specific in some matters and the causes of its low proportionality index will be explained further on in the chapter discussing the influence of all independent variables. 
Table 4: Percentage shares of ethnic minorities in population of selected municipalities, in their councils and executive bodies and final values of proportionality index

\begin{tabular}{|c|c|c|c|c|}
\hline Municipality & Leicester & $\begin{array}{l}\text { Frankfurt am } \\
\text { Main }\end{array}$ & Espoo & Cluj-Napoca \\
\hline $\begin{array}{l}\text { Percentage share of ethnic } \\
\text { minorities in population }\end{array}$ & $50 \%$ & $\begin{array}{l}47.4 \% \text { ( } 26.4 \% \text { are } \\
\text { foreign citizens) }\end{array}$ & $\begin{array}{l}15.4 \% \quad(8 \% \text { are } \\
\text { Swedish speaking } \\
\text { Finns, } 7.4 \% \text { other } \\
\text { nationalities })\end{array}$ & $\begin{array}{l}18.5 \% \quad(16.5 \% \\
\text { are Hungarians) }\end{array}$ \\
\hline $\begin{array}{l}\text { Percentage share of ethnic } \\
\text { councillors in city council }\end{array}$ & $41 \%$ & $11.8 \%$ & $9.3 \%$ & $15 \%$ \\
\hline $\begin{array}{l}\text { Percentage share of ethnic } \\
\text { councillors in executive } \\
\text { body }\end{array}$ & $50 \%$ & $8.3 \%$ & $13.3 \%$ & $\begin{array}{l}\text { Executive body } \\
\text { is not formed }\end{array}$ \\
\hline Proportionality index & 0.82 & 0.24 & 0.76 & 0.81 \\
\hline
\end{tabular}

Source: author, (Stadt Frankfurt am Main n.d. - a), (Stadt Frankfurt am Main n.d. - b), (Institutul Naţional de Statistică, 2011a), (City of Espoo, 2013), (Leicester City council n.d. - a)

\section{Special measures for minority representation}

There are at least some informal measures to promote an ethnic representation at a local level in all the selected cases. This could be very well seen in the case of Leicester, which has no formal measures to increase an ethnic representation and participation, but because it has a high share of minority population, Leicester is trying to build its image as a multicultural and multiethnic city. Therefore, there are many programs and initiatives that should help the inclusion of minority population into a local political process. The best example of these measures is probably the symbolic signing of Equality and Diversity Charter, which obliges the city officials to respect the equality of everybody and promotes the multicultural character of the city as an important value (Leicester City Council n.d. - b). City of Leicester also has a very complex official strategy to support 
and promote the participation of ethnic minorities (Leicester City Council n.d. c). Despite all these informal measures, there are no formal measures that should promote an ethnic representation in Leicester.

In other cases we can find at least some formal measures to somehow improve the participation and protection of ethnic minorities. However, in most of the cases, it did not have a direct effect on the proportionality index value. In the case of Finnish Espoo, there are some constitutional rights for the Swedish speaking community. But these rights mostly relate to the questions of language and not the political representation. Yet, it could be argued that a minority language protection helps minority citizens to simplify their communication with state institutions and, consequently, facilitates their access to elections as well. According to these language laws (Finnish Language Act, 2003), municipalities are either monolingual or bilingual, which influences which language is used as the official language in the city council meetings. The same language (or languages) is also used by the municipality to communicate with its inhabitants. City of Espoo, which is one of the examined cases in this research, is one of the bilingual municipalities.

Formal measures that have direct impact on the minority representation could be found both in Romanian Cluj-Napoca and German Frankfurt am Main. In Romania, the same rules for minority representation are used both at the central and local level. According to these rules, ethnic minority organizations may stand for an election the same way as the political parties can (Romanian law on local elections, 2004, Art. 7). If such an organization reaches a 5\% electoral threshold, but does not get any seats in the first round, it has to receive one of the remaining seats by law. However, a Hungarian minority is excluded from this rule (Romanian law on local elections, 2004, Art. 92). By itself, this rule gives some advantage to ethnic minorities; however, due to the electoral mechanics this measure is only effective in electoral districts where 13 and fewer seats are elected. In Romania, these are only municipalities with 10000 and fewer inhabitants (Council of Europe, 2009, p. 8. The simple calculation of an effective threshold ${ }^{4}$ shows that only these municipalities have an effective threshold higher than the $5 \%$ electoral threshold set by law. A situation in which a minority organization gets over 5\% threshold and no seat at the same time is, therefore, not theoretically possible in the municipalities with more than 13 seats, as it has already been said. An exclusion of Hungarian minority from this special measure is also very interesting. A logical explanation could be that a Hungarian

4 Used formula to calculate effective treshold is $\mathrm{t}=75 /(\mathrm{m}+1)$, where $\mathrm{t}$ is effective treshold and $\mathrm{m}$ is district magnitude expressed by the number of seats (Gallagher, Mitchell, 2005, p. 608). 
minority is already pretty well established in the political system and its minority organization is so strong that it is practically equal in power to some standard political parties.

The case of Frankfurt am Main represents a very specific model regarding the question of special measures, which helps minority representation. Hessen law on municipalities allows establishing of a special foreigners committee (ausländerbeirat) in the municipalities with more than 1000 foreign inhabitants. This committee has 3 to 37 members and it is elected by the foreigners living in that municipality (HGO §84-85). Adult foreigners who had their permanent residency in the municipality for at least three months before the election dispose of an active voting right to a foreigners committee. A passive electoral right (e.g. right to be elected) is held by the foreigners who have an active right but with the residency in the municipality for 6 months. For this purpose, a foreigner is considered anyone who does not have German citizenship and German citizens with dual citizenship (HGO §86). The duties of this committee are defined quite loosely in Hessen law. The committee should represent the interests of foreign citizens and it should advise city council in all matters concerning foreigners. Magistrate (local executive body in Hessen) is obliged to inform the committee about all the decisions that concern foreigners (HGO §88). The fact that foreigners (who represent up to $26.4 \%$ of inhabitants in Frankfurt) do not have a voting right, but they are included into the calculation of proportionality index, naturally distorts the final result. That is why the proportionality index is so low in Frankfurt in comparison to other cases. However, it cannot be said that foreigners have no representation at all, as they have their own institution to represent them. If we redid the calculation of proportionality index for Frankfurt ${ }^{5}$ without the foreigners, the final result would be 0.56 , which is much closer to the other cases.

\section{Electoral system}

Various experts (Fiala, 2004; Sartori, 1997; Lijphart ,1999) on electoral system say that a proportional list system helps the representation of minorities by its natural mechanics. In case of plurality vote systems, the representation of minority groups is only possible if the minority group is geographically concentrated in some of the electoral districts so that it has a majority in that district. These presumptions were not fulfilled in the examined cases. For example, a proportional

5 In this revisited calculation, only citizens which are considered to be Germans with migration origin (migrationshintergrund) are considered minority population.These make up to $21 \%$ of all citizens in Frankfurt (Stadt Frankfurt am Main n.d. - a) 
list system with a strong level of vote personalization ${ }^{6}$ is used in Frankfurt am Main. Such a system should, according to the theory, help voters to prefer their candidate. This should supposedly help ethnic candidates, presuming that voters vote ethnically. However, Frankfurt has the lowest proportionality of all the selected cases ${ }^{7}$. One of the possible explanations could be that the high level of vote personalization could also help voting discrimination as it is suggested by research performed by Alex Street. In his research, he introduced two different candidate lists to two groups of respondents. The first list consisted of the group of candidates with German names. The other list consisted of the candidates with the same parameters (age, gender and education), but some of them had Turkish names (Street, 2013, p. 3). The result showed that German voters tend to some extent to discriminate minority candidates. According to the results, this trend was the strongest with right oriented conservative voters (Street, 2013, p. 3). Another explanation could be that minority voters in Frankfurt simply do not vote ethnically.

A specific type of plurality vote system called block vote is used at a local level in the case of British Leicester. The system is similar to the first-past-thepost system used in the elections to Westminster, but a voter can distribute as many votes as there are elected seats. There are 22 electoral districts with 2-3 seats in Leicester (The City of Leicester (Electoral Changes) Order, 2002). Block vote does not allow cumulating the votes for one candidate. When calculating the results of the elections, candidates are sorted by the number of votes they got and as many candidates from the top of the list as is the number of elected seats are elected. As it is with all plurality systems, this one is also very disproportional, while its disproprotionality is decreasing as the districts become bigger (Lebeda, 2004, p. 23). Therefore, the small 2-3 seats electoral districts, which could be found in Leicester, are almost as much disproportional as first-past-the-post system. Nonetheless, Leicester has the highest value of the proportionality index of all the examined cases. This could again have several reasons. The first cause could be that all of the non-British population together comprises a bit more than half of the population, which dramatically lowers the disproportionality of the electoral results. Another explanation offered is the already mentioned argument

6 According to the law on elections, voter has as many votes as there are elected seats. These votes could also be cumulated (as much as three votes for one candidate). Panachage is also possible (that means distribution of the votes between different candidate lists) or whole candidate list could be selected. If you decide for the last option, then you can cross out any candidate from the candidate list and he will not get any vote.

7 And that is even when we exclude the foreigners from the calculation as it was already explained. 
about the geographical concentration of the minorities. According to city statistic data, ethnic minority citizens were having a majority in some of the electoral wards (Leicester City Council, 2011).

Romanian Cluj-Napoca and Finnish Espoo fulfilled the expectations about the effects of their electoral systems on minority representation. Both these cities use a proportional system in their local elections (with vote personalization in case of Espoo) and both their final values of proportionality were relatively high.

\section{Voting right}

Both types of voting right (passive and active) naturally have influence on the composition of political representation. As it has already been mentioned, a standard voting right in local elections in European countries is a voting right for the citizens of all the EU countries. Permanent residency in the relevant municipality for a certain amount of time is also usually required, and this period is usually longer for a passive voting right. A person can be elected if he or she had permanent residency in the municipality for the last 12 months in the UK. In Hessen this period is 6 months, in Romania 3 months and in Finland only 51 days (Romanian law on local elections, 2004, Art. 3), (Jääskeläinen, 2010, 18-19), (Representation of the People Act, 1983), (Electoral Commission n.d.), (KWG 2005).

The biggest influence of the voting right to the level of ethnic representation could be observed in Leicester. Both passive and active right in British local elections is- besides all the EU citizens, also extended to the citizens of Commonwealth countries. This is an important factor in case of Leicester, because a majority of its ethnic inhabitants is either from the EU or Commonwealth countries (Leicester City council n.d. - a). That is also naturally reflected in an ethnic composition of city council, whose ethnic councillors have their roots in Commonwealth countries (mostly in India) as well.

Non EU foreigners have no voting right in Romania, but they do have it in Finland, if they lived in the country for at least the last 2 years. However, a voting right did not play a major role in any of these two cases, because the main ethnic minority group in Romania are Hungarians who were born in Romania. That is the same in Finnish Espoo where the biggest minority group comprises Swedish speaking Finns, who also have Finnish citizenship. Finally, foreigners have no voting right to the city council in Frankfurt, but they can vote and be elected to the foreigners committee (ausländerbeirat) as it has already been mentioned earlier. 


\section{Nature of ethnic representation}

As for the nature of ethnic representation, a relationship could be observed between the nature of ethnic minority (meaning whether it is of migration origin or not) and the nature of its political representation. In the observed municipalities with autochthon minorities (Espoo, Cluj-Napoca) these minorities were represented by established ethnoregional parties. On the other hand, in the municipalities with migrant minorities (Leicester, Frankfurt) these minorities were represented by non-ethnic, traditional nationwide parties. It could be argued that historical minorities had more time to better establish themselves within the political system and, therefore, existence of their own ethnic parties could be expected. The case of Leicester demonstrates that with an existence of a plurality vote electoral system, which according to Duverger and Sartori (Lebeda, 2004, p. 5355) should be reductive towards smaller parties, ethnic minorities rather stand for election on the candidate list of some big, nationwide political parties rather than their own parties. The influence of an electoral system on the nature of political representation in Leicester was thus much higher than its influence on the proportionality of representation. The heterogeneity of minority population in Leicester could be considered another obstacle for forming a strong ethnic party. It is also interesting to observe which parties were used for a candidacy of minority candidates in cases where there were no ethnic or regional parties (Frankfurt, Leicester). In both cities, it was mostly left and centre-left oriented parties. From all eleven elected ethnic councillors in Frankfurt, five were elected for the Green Party, two for Social democratic party and Die Linke and ELF Piraten got each one ethnic councillor. Right-wing Christian democrats (CDU) got only one ethnic councillor. The last of all 11 ethnic councillors was elected as an independent candidate. This trend is also confirmed by the study conducted by Heinrich Böll Stiftung, which focuses on ethnic councillors in whole Germany. According to this study, $34.3 \%$ of all councillors with migration background are elected for Social Democratic Party (SDP) and 25\% for Green Party. Die Linke and CDU got each 13.6\% share of all ethnic councillors in Germany (Schönwälder, Sinanoglu, Volkert 2011, 35). Even though the case of Frankfurt corresponds just partially with these numbers, it confirms the trend that most of the ethnic councillors were elected for SDP, Green Party or Die Linke.

In case of Leicester all 22 ethnic councillors were elected for the Labour Party. This correlates with the survey from 2012 (Lord Ashcroft Polls, 2012) which says that the Labour Party is the party with the biggest support amongst minority voters. This survey also shows that they support Labour party because of their lower social status and because the ethos of some of the minority religions 
(Sikhs, Muslims) is closer to Labour Party (Lord Ashcroft Polls, 2012). Probably because of an electoral system, no local parties could be found in Leicester

\section{Conclusion}

The main relationship which could be observed on the examined cases (and, therefore, could not be considered as a universally plausible model) is a relation between the nature of a ethnic minority and the nature of its political representation. However as it was already noted, used methodology is quite limited when it comes to deriving of strong causal relations and as such, this relation should be considered only a correlation which could be later confirmed as causality with some further research focused on this question.

Table 5: Nature of ethnic representation and values of relevant variables

\begin{tabular}{|c|c|c|c|}
\hline & Independent variables & & Dependent variable \\
\hline Case & Electoral system & $\begin{array}{l}\text { Nature of ethnic minori- } \\
\text { ty (immigrant } x \text { tradi- } \\
\text { tional) }\end{array}$ & $\begin{array}{l}\text { Nature of ethnic repre- } \\
\text { sentation }\end{array}$ \\
\hline Leicester & Majoritarian (Block vote) & Immigrant & Standard political parties \\
\hline Frankfurt am Main & $\begin{array}{l}\text { Proportional with vote } \\
\text { personalization (high level } \\
\text { of personalization) }\end{array}$ & Immigrant & Standard political parties \\
\hline Espoo & $\begin{array}{l}\text { Proportional with vote } \\
\text { personalization }\end{array}$ & $\begin{array}{l}\text { Mixed model - half of the } \\
\text { minority population are } \\
\text { immigrants, the other half } \\
\text { is traditional community } \\
\text { of Swedish-spealing Finns }\end{array}$ & $\begin{array}{l}\text { Swedish community is } \\
\text { represented by ethnic } \\
\text { party }\end{array}$ \\
\hline
\end{tabular}

$\begin{array}{lll}\text { Cluj-Napoca } & \begin{array}{l}\text { Proportional with no per- } \\ \text { sonalization of vote }\end{array} & \begin{array}{l}\text { Traditional }-(90 \% \text { of all Ethnic party (formally } \\ \text { minority population are minority organization) }\end{array} \\ & \begin{array}{l}\text { Hungarians, rest is com- } \\ \text { posed of other traditional }\end{array} \\ & \text { minorities) }\end{array}$

Source: author 
Table 5 shows that in the cases with minorities of migration origin, ethnic councillors are usually elected for one of the non-ethnic nationwide parties. On the other hand, in case of historical minorities these councillors are elected mostly for their own ethnic or regional parties. This could confirm the basic assumption which we can have towards the political representation of autochthon minorities, that these minorities are better grounded within the political structures and thus have their own institutional structure (usually in the form of ethnic or regional party) which serves its representation.

Table 6 puts all independent variables to relationship with final value of proportionality index of ethnic representation. The final values are surprisingly similar in all cases with the exception of Frankfurt am Main. However, a lower value in case of Frankfurt is probably caused by a different model of representation where foreigners cannot vote in elections, but have their own special council.

Some influence on proportionality index could be observed with a voting right. It plays an important role especially in the municipalities with immigrant minorities, because the members of historical minorities usually have the same citizenship (and, therefore, also a voting right) as the majority population. The best example here is probably Leicester, where an extended voting right to all Commonwealth citizens (where most of the non-British citizens in Leicester belong to) dramatically changes the composition of electorate.

As for the electoral system, which was expected to have major impact on the minority representation, no clear conclusions could be made. Basic assumptions about the influence of electoral system were not confirmed in the examined cases. That is mostly because of its very specific parameters and it does not mean that we can simply deny such assumptions, but it means that they could not be considered universally plausible and that a research of local politics relies a lot on the specific context. This could be demonstrated on the electoral system used in Frankfurt, which should help to include minority candidates the most by its high level of personalization. However, its final value of proportionality index is the lowest from all the cases. On the other hand, Leicester uses a block vote electoral system which is based on the majority rule and as such it should be the worst system from all the cases regarding minority representation. Despite this, Leicester has the highest proportionality index. 
Table 6: Proportionality index and relevant independent variables

\begin{tabular}{|c|c|c|c|c|}
\hline & Independent variab & bles & & Dependent \\
\hline Case & Electoral system & Electoral right & Special measures & $\begin{array}{l}\text { Index of pro- } \\
\text { portionality of } \\
\text { ethnic repre- } \\
\text { sentation }(R)\end{array}$ \\
\hline Leicester & $\begin{array}{ll}\text { Plurality } & \text { wote } \\
\text { (Block wote) }\end{array}$ & $\begin{array}{l}\text { Extended to spe- } \\
\text { cific group of non- } \\
\text { citizens (Com- } \\
\text { monwealth) }\end{array}$ & $\begin{array}{l}\text { Informal initiatives, to } \\
\text { support the political } \\
\text { participation of ethnic } \\
\text { minorities }\end{array}$ & $0.82(\mathrm{UK} 0.24)$ \\
\hline $\begin{array}{l}\text { Franlufurt am } \\
\text { Main }\end{array}$ & $\begin{array}{l}\text { Proportional with } \\
\text { vote personalizz- } \\
\text { tion (high level of } \\
\text { personalization) }\end{array}$ & $\begin{array}{l}\text { Electoral right for } \\
\text { local and EU citi- } \\
\text { wens }\end{array}$ & $\begin{array}{l}\text { Specific model, where } \\
\text { participation of ethnic } \\
\text { minorities is solved by } \\
\text { special council }\end{array}$ & $0.24($ GER 0,09$)$ \\
\hline Espoo & $\begin{array}{l}\text { Proportional with } \\
\text { vote personalizz- } \\
\text { tion }\end{array}$ & $\begin{array}{l}\text { Broad electoral } \\
\text { right which in- } \\
\text { cludes foreigners } \\
\text { under certain cir- } \\
\text { cumatances }\end{array}$ & $\begin{array}{l}\text { Language laws for } \\
\text { Swediah speaking } \\
\text { community in consti- } \\
\text { tution. No measures } \\
\text { that influence directly } \\
\text { political representa- } \\
\text { tion }\end{array}$ & $0.76(F I 0,83)$ \\
\hline Cluj-Napoca & $\begin{array}{l}\text { Proportional with } \\
\text { no personalization } \\
\text { of wote }\end{array}$ & $\begin{array}{l}\text { Electoral right for } \\
\text { local and BU citi- } \\
\text { vens and }\end{array}$ & $\begin{array}{l}\text { Fomal messures that } \\
\text { should belp minority } \\
\text { representation (not } \\
\text { used in this case) }\end{array}$ & $0.81($ ROMI, $)$ \\
\hline
\end{tabular}

Source: author 
The last observed independent variable, special measures for minority representation, showed that some kind of measures could be found in all the examined cases. However, the nature of these measures differed a lot from case to case. The case of Frankfurt am Main shows that strong institutional measures related to minority representation could lead to the creation of a unique and specific model of representation. Romanian Cluj-Napoca shows very well that quotas as the direct measure to support minority representation rely a lot on their specific settings or they may prove to be only a formality.

As it was already mentioned in the introduction of this paper, there has been no coherent research about the political representation of ethnic minorities at the local level. The main contribution of this paper is therefore more detailed and systematic look to the new topic. However, even though this research was limited in size, some interesting patterns emerged which would probably deserved deeper examination. One of them could be the importance of electoral systems for minority representation at local level. This research on the limited number of cases didn't confirm any of the generally accepted presumptions about the electoral systems and its influence on minority representation. The question is to what extent is this caused by specificity of the selected cases or whether it is some general trend on the local level.

This paper also suggests that non-autochthon minorities are having more difficulties to get their representation as well as that they are usually represented by non-ethnic parties. Again, as this suggestion is based just on examination of four cases it is difficult to make strong conclusions, but if this presumption is to be confirmed, it would have meant that when it come to political inclusion, more attention should be paid to non-autochton communities, because their situation is less transparent and also more complicated.

The topic of quotas, which was already mentioned, would also deserve some further attention as the empirical evidence from the examined cases shows that theoretical and practical effects of quotas can differ a lot from each other. Therefore some future research focused on quotas and its effect on representation at local level could give us some answers about which type of quotas are effective in this context or even whether there should be used any quotas at all.

\section{References}

ADEGEHE, A. K.: Federalism and ethnic conflict in Ethiopia : a comparative study of the Somali and Benishangul-Gumuzregions. Doctoral Thesis, Leiden Univeresity, 2009. $312 \mathrm{~s}$. 
ANDERSON, B.: Imagined Communities: Reflections on origin and spread of nationalism. London, New York: Verso, 1991. 224 s. ISBN 0-86091-546-8.

BARŠA, P.: Národnostní konflikt a plurální identita. in: Barša, P.; Strmiska, M. (eds.): Národní stát a etnický konflikt: politologická perspektiva. Brno: Centrum pro studium demokracie a kultury, 1999. 329 s. ISBN 80-8595952-6.

BLOEMRAAD, I.; SCHÖNWALDER, K.: Immigrant and Ethnic Minority Representation in Europe: Conceptual Challenges and Theoretical Approaches. West European Politics, 2013. roč. 36 č. 3. str. 564-579.

CITY OF ESPOO.: City of Espoo: Pocket Statistics 2013. [online]. [cit. 201404-4]. 2013. Available at http://www.espoo.fi/en-US/City_of_Espoo/ Information_about_Espoo/Research_and_statistics.

COUNCIL OF EUROPE.: Structure and Operation of Local and Regional Democracy: Romania. Strassbourg: Council of Europe, Steering Committee on Local and Regional Authorities, 2009. 28 s.

ELECTORAL COMMISSION.: Can you stand for elections?. [online]. [cit. 2014-04-10]. (n.d.). Available at http://www.electoralcommission.org.uk/ data/assets/pdf_file/0007/141784/Part-1-Can-you-stand-for-election-LGEW. pdf

ERIKSEN, T. H.: Etnicita a nacionalismus: antropologické perspektivy. Praha: Sociologické nakladatelství, 2012. 352 s. ISBN 978-80-7419-053-7.

FIALA, P.; STRMISKA, M.: Teorie politických stran. Brno: Barrister \& Principal, 1998. 263 s. ISBN 80-85947-31-5.

FINNISH LANGUAGE ACT.: Language Act (423/2003). Ministry of Justice, Finland. [online]. [cit. 2014-03-27]. 2003. Available at http://www.finlex.fi/ en/laki/kaannokset/2003/en20030423.pdf.

GAllagher, M.; MITCHELl, P. (eds.): The Politics of Electoral Systems. New York: Oxford University Press, 2005. 662 s. ISBN 0199238677.

GELLNER, A.: Národy a nacionalismus. Praha: Hř́ibal, 1993. 158 s. ISBN 80901381-1-X.

GILLHAM, B.: Case Study Research Methods. London: Continuum International Publishing, 2010. 106

s. ISBN 9780826447968.

HEINELT, H.; HLEPAS, N. K.: Typologies of Local Government System. in:

Bäck, H.; Heinelt, H.; Magnier, A. (eds.): The European Mayor: Political Leaders in the Changing Context of Local Democracy. Wiesbaden: VS Verlag für Sozialwissenschaften, 2006. 386 s. ISBN 978-3-531-14574-7.

HESSISCHE GEMEINDEORDNUNG (HGO).: [online]. [cit. 2014-03-27]. 
2005. Available at http://www.rv.hessenrecht.hessen.de/jportal/portal/t/xm4/ page/bshesprod.psml?doc.hl=1\&doc.id=jlr-GemOHE2005rahmen\%3Ajuris1 r00\& showdoccase $=1 \&$ documentnumber $=1 \&$ numberofresults $=218 \&$ doc . part $=\mathrm{R} \&$ doc. price $=0.0 \&$ paraparamfr $=$ true.

HESSISCHES KOMMUNALWAHLGESETZ (KWG): [online]. [cit. 2014-04-10]. 2005. Available at <http://www.rv.hessenrecht.hessen. de/jportal/portal/t/k1 i/page/bshesprod.psml?doc.hl=1\&doc.id=jlrKomWGHE2005rahmen\%3Ajuris-lr00\&showdoccase $=1 \&$ documentnumbe $\mathrm{r}=1$ \&numberofresults $=85 \&$ doc. part $=X \&$ doc. price $=0.0$ \&paramfrom $H L=$ true \#focuspoint>

HOROWITZ, D.: Ethnic Groups in Conflict. Berkeley: University of Carolina Press. $715 \mathrm{~s}$.

IDNES.CZ. Ve Skopji se střetli Makedonci s Albánci. Zůstaly desitky zraněných. [online]. 3-3-2013, [cit. 2014-04-14]. Available at http://zpravy.idnes.cz/ nasilne-protesty-v-makedonii-djn-/zahranicni.aspx?c=A130303_085633 zahranicni_brm.

INSTITUTUL NAŢIONAL DE STATISTICĂ.: 8. POPULATIA STABILA DUPA ETNIE - JUDETE, MUNICIPII, ORASE, COMUNE. [online]. 2011a. Available at http://www.recensamantromania.ro/wp-content/ uploads/2013/07/sR_Tab_8.xls.

JÄÄSKELÄINEN, A.: Finnish Election System: Overview. Ministry of Justice, Finland. [online]. [cit. 2014-03-27]. 2010. Available at http://oikeusministerio. fi/material/attachments/om/julkaisut/6Fioq3rxv/OMTH_72_2010_Finnish_ Election_System_Overview_32_s.pdf

LEBEDA, T.: Stručný přehled volebních systémů. in: NOVÁK, M.; LEBEDA, T. a kol.: Volební a stranické systémy: ČR v mezinárodním srovnání. Dobrá Voda: Čeněk, 2004. 485 s. ISBN 80-86473-88-0.

LEICESTER CITY COUNCIL.: Equality and Diversity Charter. [online]. [cit. 2014-04-10]. (n.d. - b) Available at http://www.leicester.gov.uk/ EasySiteWeb/GatewayLink.aspx?alId=128310.

LEICESTER CITY COUNCIL.: Ethnicity. [online]. [cit. 2014-03-27]. (n.d.a). Available at http://www.leicester.gov.uk/your-council-services/counciland-democracy/city-statistics/other-statistics/historical-interest/census2001/ ethnicity/.

LEICESTER CITY COUNCIL.: Our commitment to equality. [online]. [cit. 2014-03-27]. (n.d. - c). Available at http://www.leicester.gov.uk/yourcouncil-services/council-and-democracy/key-documents/equality-anddiversity/our-commitment-to-equality//

LEICESTER CITY COUNCIL.: The Diversity of Leicester: Summary of Key 
Facts: 2011. [online]. [cit. 2014-03-27]. 2011. Available at http://www. leicester.gov.uk/EasySiteWeb/GatewayLink.aspx?alId=89093.

LEICESTER MERCURY: EDL march passes off peacefully. [online]. 30-62013, [cit. 2014-04-14]. Available at http://www.leicestermercury.co.uk/ EDL-march-passes-peacefully/story-19155723-detail/story.html.

LIJPHART, A.: Democracy in Plural Societies: a Comparative Exploration. New Haven: Yale University Press, 1980. 244 s. ISBN 0300024940.

LIJPHART, A.: Patterns of Democracy. New Haven: Yale University Press, 1999. 351 s. ISBN 0-300-07893-5.

LIJPHART, A.: The Politics of accommodation : pluralism and democracy in the Netherlands. Berkeley: University of California Press, 1968. 231 s. ISBN 0520029003.

LIPSET, S. M.; ROKKAN, S.: Party systems and voter alignments: cross-national perspectives. New York: Free Press, 1967. 554 s. ISBN 9780029191507.

LORD ASHCROFT POLLS.: Ethnic minority voters and the Conservative Party. [online]. [cit. 2014-04-14]. 2012. Available at http://lordashcroftpolls. com/2012/04/ethnic-minority-voters-and-the-conservative-party-2/

REPRESENTATION OF THE PEOPLE ACT 1983: [online]. [cit. 2014-03-27]. 1983. Available at http://www.legislation.gov.uk/ukpga/1983/2/contents ROMANIAN LAW ON LOCAL ELECTIONS.: Law for the election of local public administration authorities 67/2004. Official Gazette of Romania, Part I, no. 271. [online]. [cit. 2014-04-20]. 2004. Available at http://aceproject. org/ero-en/regions/europe/RO/law-67-2004-for-the-election-of-local-public/ view.

SARTORI, G.: Comparative Institutional Engineering: an Inquiry into Structures, Incentives and Outcomes. New York: New York University Press, 1999. 217 s. ISBN 0814780636.

SCHÖNWÄLDER, K.; SINANOGLU, C.; VOLKERT, D.: Vielfalt sucht Rat: Ratsmitglieder mit Migrationshintergrund in deutschen Grossstädten. Heinrich Böll Stiftung. [online]. 2011. Available at http://www.mmg.mpg. de/fileadmin/user_upload/Publikationen/Pdf/Vielfaltsuchtrat.pdf.

SMITH, A. D.: The ethnic origins of nations. Oxford: Blackwell, 1986. $312 \mathrm{~s}$. ISBN 978-0-631-16169-1.

SMITH, A. D.; HUTCHINSON, J. (eds.).: Ethnicity. Oxford: Oxford University Press, 1996. 448 s. ISBN 0-19-289274-6.

STADT FRANKFURT AM MAIN.: Bevölkerung. [online]. [cit. 2014-03-27]. (n.d. - a). Available at http://www.frankfurt.de/sixcms/detail.php?id=2811\&_ ffmpar[_id_inhalt] $=7524$.

STADT FRANKFURT AM MAIN.: Geschäftsstelle der Kommunalen Ausländer- 
und Ausländerinnenvertretung der Stadt Frankfurt am Main (KAV). [online]. [cit. 2014-03-27]. (n.d. - b). Available at http://www.frankfurt.de/sixcms/ detail.php?id=2893\&_ffmpar[_id_inhalt] $=102272$.

STREET, A.: Representation Despite Discrimination: Minority Candidates in Germany. Political Research Quarterly. November 2013.

STRMISKA, M.: Centrum, periferie a národotvorný proces. in: Barša, P.; Strmiska, M. (eds.): Národní stát a etnický konflikt: politologická perspektiva. Brno: Centrum pro studium demokracie a kultury, 1999. 329 s. ISBN 8085959-52-6.

SWIANIEWICZ, P.: An Empirical Typology of Local Government Systems in Eastern Europe. Local Government Studies, 2014, Vol. 40, No. 2. 292-311 s. TESAŘ, F.: Etnické konflikty. Praha: Portál, 2007. 251 s. ISBN 978-80-7367097-9.

THE CITY OF LEICESTER (ELECTORAL CHANGES) ORDER 2002. [online].[cit. 2014-03-27]. 2002. Available at http://www.legislation.gov.uk/ uksi/2002/2988/schedule/made.

TÝDEN.CZ: Protest. Mad'aři v Rumunsku se stále derou o autonomii. [online]. 27-10-2013, [cit. 2014-04-14]. Available at http://www.tyden. cz/rubriky/zahranici/evropa/protest-madari-v-rumunsku-se-stale-derou-oautonomii_287062.html\#.U29Q6YF_u_B.

VAN EVERA, S.: Guide to the Methods for Students of Political Science. Ithaca, London: Cornell University Press, 1997. 136 s. ISBN 978-0-8014-8457-5. 